\title{
The Effect of Gene Mutations on Disease Severity Scores in Pediatric Familial Mediterranean Fever Patients
}

\section{Ailevi Akdeniz Ateşi Tanılı Çocuk Hastalarda Gen Mutasyonlarının Hastalık Ciddiyet Skorları Üzerine Etkisi}

\author{
'Vildan Güngörer (D, , Alaaddin Yorulmaz (D), 'Şükrü Arslan (D)
}

'Department of Pediatric Rheumatology, Selçuk University Medical School, Konya Turkey

${ }^{2}$ Department of Pediatrics, Selçuk University Medical School, Konya, Turkey

\section{Correspondence}

Vildan Güngörer, Department of Pediatric Rheumatology, Selçuk University School of Medicine, Konya University School of Medicine, Konya, Turkey

E-Mail: vildan_61183@hotmail.com

\section{How to cite ?}

Güngörer V, Yorulmaz A, Arslan \$. The Effect of Gene Mutations on Disease Severity Scores in Pediatric Familial Derg. 2022:32(1):19-26.

\begin{abstract}
Objectives: Familial Mediterranean Fever (FMF) is a self-limiting autoinflammatory disease. In order to better understand the prognosis of diseases, disease severity scores are used. The aim of this study is to determine the effect of genetic mutations on disease severity scores in children with FMF. Methods: Patients aged 0-18 years who were diagnosed with FMF according to Yalçınkaya-Özen diagnostic criteria and whose gene analysis was performed were evaluated retrospectively. Pras et al's scoring system, Mor et al's scoring system and International severity score of FMF (ISSF) scoring system were applied to all patients. Genotypes were compared according to disease severity scores.

Results: When the patients were divided into 4 groups as M694V homozygous, heterozygous, M694V/ other allele combined heterozygous and other mutations, according to the score of Pras et al., the frequency of mild disease tended to be less in the M694V homozygous group. When the patients divided as homozygous M694V, heterozygous M694V, heterozygous E148Q, heterozygous M694V/ M680l combined mutations, according to the score of Pras et al., mild disease was found to be less common in the homozygous M694V group. When patients were divided into homozygous and heterozygous M694V (combined with other allele or single) groups, the disease was more severe in the homozygous M694V group according to the three scoring systems. In the concordance analysis between scoring systems, while a good agreement was found between Mor et al.'s scoring system and ISSF, the agreement with Pras et al.'s scoring system was weak

Conclusions: Based on the scoring system described by Pras et al., the rate of severe disease was higher in patients with homozygous M694V allele, whereas the rate of mild disease was statistically significantly higher in the heterozygous group (combined with other allele or single) compared with homozygous group. From this, we can conclude that the M694V homozygous mutation causes more severe disease than the M694V heterozygous mutation, and even more severe disease than its combination with another pathogenic mutation, one of which is M694V.
\end{abstract}

Keywords: Familial Mediterranean Fever, genotype, disease severity scores, clinic, treatment

öz

Amaç: Ailevi Akdeniz Ateşi (AAA) kendi kendini sınılayan otoinflamatuar bir hastallktır. Hastalıklarınprognozunu daha iyi anlamak için çesitli klinik kriterlerin bir kombinasyonuna göre puanlanan hastalık şiddeti skorları kullanılır. Bu çalışmanın amacl, AAA'lı çocuklarda genetik mutasyonların hastalık şiddeti skorlarına etkisini belirlemektir.

Gereç ve Yöntemler: Yalçınkaya-Özen tanı kriterlerine göre AAA tanısı konan ve gen analizi yapılan 0-18 yas arası hastalar retrospektif olarak değerlendirildi. Tüm hastalara Pras ve arkadașlarının skorlama sistemi, Mor ve arkadașlarının skorlama sistemi ve Uluslararası AAA siddet skoru (ISSF) skorlama sistemi uygulandı. Hastalar genetik mutasyonlarına göre sinıfandirilarak hastalık şiddeti skorları karşıllaştıııldı.

Bulgular: Hastalar M694V homozigot, heterozigot, M694V/diğer alel birlesikheterozigot ve diğer mutasyonlar olarak 4 gruba ayrldığında Pras ve arkadașlarının hastalık ağırlık skoruna göre M694V homozigot olanlarda hafif hastalık siklğı daha az bulunduHastalar en sık bulunan homozigot M694V, heterozigot M694V, heterozigot E1 48Q ve birleşik heterozigot M694V/M680l mutasyonlar olarak 4 gruba ayrildığında. Pras ve ark.'In skorlama sistemine göre homozigot M694V grubunda hafif hastalık sıklığı daha az saptandı. Hastalar homozigot M694V grubu ve heterozigot M694V (diğer bir alelle birlesik ya da tek) grubu olarak ikiye ayrıldı̆̆ında, üc skorlama sistemine göre homozigot M694V grubunda hastallik daha şiddetliydi. Skorlama sistemleri arasındaki uyum analizinde Mor ve ark. ve ISSF skorlama sistemleri arasında güçlü bir uyum saptanırken, Pras ve ark. skorlama sistemi ile diğer skorlar arası uyum zayıf bulundu.

Sonuçlar:According to the scoring system defined by Pras et al., patients with homozygous M694V allele had a higher rate of severe disease than all other groups. Buradan M694V homozigot mutasyonun, M694V heterozigot mutasyondan daha şiddetli hastallik yaptığı ve hatta biri M694V olmak üzere diğer bir patojenik mutasyon ile kombinasyonundan da daha şiddetli hastalık yaptığı sonucuna varabiliriz.

Anahtar Kelimeler: Ailevi Akdeniz Ateşi, genotip, hastalık şiddet skorları, klinik, tedavi 


\section{Introduction}

Familial Mediterranean Fever (FMF) is a self-limiting autoinflammatory disease characterized by inflammation of the serosal surfaces and recurrent episodes of fever along with abdominal pain, arthralgia, arthritis, serositis, and erysipelas-like rash, typically lasting 6-72 hours during attacks (1-3). Although it is seen all over the world, its incidence is higher in ethnic groups living in the Eastern Mediterranean geography, especially Turks, Arabs, Armenians and Jews, compared to other countries. Its prevalence in these geographies varies between 1 in 500- 1000 (1). The most serious complication of the disease is amyloidosis, which can cause longterm morbidity and mortality (4). The Mediterranean fever (MEFV) gene is an autosomal gene that follows the autosomal recessive mode of inheritance and is present on the short arm of the sixteenth chromosome (5). Although only five mutations were found in $85 \%$ of the patients, 385 mutations were detected according to the latest data from the Infevers website $(6,7)$. The most common mutations were M694V, M680I, M694I, and V726A mutations in exon 10, which are believed to be associated with disease severity.

The scoring systems described by Pras et al. (8) and Mor et al. (9) and the International Severity Score of Familial Mediterranean Fever (ISSF) (10) are the most commonly used scoring systems to determine disease severity in FMF. Thanks to these scoring systems, it is possible to classify FMF patients according to disease severity and to try to predict their prognosis. Various demographic, clinical and laboratory findings are used in scoring systems. The scoring systems used in FMF are shown in Table 1.

To date, there are a limited number of studies evaluating the relationship between disease severity scores and gene mutations. For this purpose, we aimed to examine the relationship between three different disease severity scores and gene mutations in patients followed up at our clinic.

\section{Methods}

\section{Patients}

Patients aged 0-18 years, who were diagnosed with FMF and underwent gene analysis between 2017-2020 in the Pediatric Rheumatology outpatient clinic of Selcuk University Faculty of Medicine, were included in the study.According to the diagnostic criteria by Yalçınkaya and Özen, the presence of at least two of the criteria among fever $>38 \mathrm{C}^{\circ}$ measured in the axillary area, abdominal pain, chest pain, arthritis, and a positive family history, lasting 6-72 hours in at least three attacks, were considered sufficient for the diagnosis (11). Patients whose genetic analysis was not performed and patients who did not comply with their follow-up and treatment were not included in the study.

Demographic, clinical, genetic, and laboratory characteristics of these patients were recorded retrospectively from their records and the computer information system. In light of this information, the patients' disease was scored according to the disease severity scoring system by Pras et al. and Mor et al. as well as the ISSF, and the disease severity was classified as mild, moderate, and severe. FMF disease severity scoring systems are summarized in Table 1.

\section{Genetic Analysis of MEFV gene}

DNA isolation was performed from the peripheral blood samples of the patients and 22 mutations (M694V, M694I, M680I, V722M, V726A, E148Q, R202Q, R761H，P369S, A744S, E230K, K695R, L110P, U148Q, F479L, R761U, M694 del, 1692 del, T681l, A408G, T267I, and E167D) in the 2nd, 3rd, 5th and 10th exons of the MEFV gene were analyzed by fragment analysis. In cases where no mutations could be detected in these, the whole gene sequencing technique, which is an advanced genetic analysis technique, was used. Gene analysis was performed from the mother and father for the detection of combined heterozygous mutations.

The relationship between common genotypes and alleles and disease severity scores were investigated. Mutations were divided into four groups, as homozygous, heterozygous, heterozygous combined, and no mutation, for comparison and evaluated both in terms of disease severity scores.

In addition, patients were divided into four groups as homozygous M694V, heterozygous M694V, heterozygous M694V/other allele combined, and other mutations, and the groups were compared with each other in terms of disease severity scores. Homozygous M694V, heterozygous M694V, heterozygous El48Q, and heterozygous M694V/M680I combined mutations, which were the most common four genetic analysis results in our study, were similarly compared in terms of disease severity scores.

The study was approved by the local ethics committee on June 17, 2020 with the decision number 2020/258.

\section{Statistical Analysis}

IBM SPSS version 21 and SDATA version 15.1 were used for the statistical analyses. Descriptive statistics were described as mean $\pm S D$, minimum, and maximum. Frequency analysis was performed for categorical data. Chi-Square and Fisher's Exact tests were used to compare categorical variables. Categorical data, which were found to be correlated in the Chi-Square test, were subjected to Chi-Square Trend and Post hoc analyses. Numerical data were evaluated using the Mann-Whitney Utest. A value of $\mathrm{p}<0.05$ was considered statistically significant.

\section{Results}

\section{Demographic and Clinical Characteristics}

Of the patients included in the study, 149 (49.1\%) were female and 154 (50.8\%) were male. The demographic and clinical characteristics of the patients are summarized in Table 2. The median age of the patients was 10 years (min-max: 10 months-18 years). The 
median age at diagnosis was 6 years (min-max: 10 months- 18 years). The median time from the onset of the complaints to the diagnosis was calculated as 2 years (min-max: 2 months-13 years). While the number of patients diagnosed under the age of 10 was 220 $(72.6 \%)$, the number of patients diagnosed over the age of 10 was $83(27.3 \%)$ (Table 2 ).

When the patients were evaluated in terms of clinical features, abdominal pain was seen in 290 patients (95.7\%) and was the most common clinical feature. This was followed by fever in 283 patients (93.3\%), joint pain in 164 patients (54.1\%), fatigue in 80 patients $(26.4 \%)$, chest pain in 64 patients $(21.1 \%)$, and arthritis in 46 patients (15.2\%) were followed. Detailed clinical examination is given in Table 2.The diagnosis of the patient with renal involvement was made by kidney biopsy.

\section{Genetic Characteristics}

While mutations were detected in 271 (89.4\%) of the patients, no mutation was detected in 32 (10.6\%) patients. Heterozygous mutations were detected in $136(44.8 \%)$ patients, combined heterozygous mutations in 76 (25\%) and homozygous mutations in 59 (19.4\%) patients.
When the allele frequencies in the patients included in the study were examined, in total, mutations were detected in 359 alleles. The M694V allele was seen in 157 patients (43.7\%) and was found to be the most common allele. The second and third most common alleles were $\mathrm{M} 680 \mathrm{I}$ in 61 (16.9\%) patients and V726A in $49(13.6 \%)$ patients, respectively. Other common alleles included E148Q, R202Q.

When the mutations of the patients were examined, the most common mutation was M694V heterozygous mutation in $63(23.2 \%)$ patients. This was followed by M694V homozygous mutation detected in 43 patients (15.8\%). El48Q heterozygous mutation detected in 27 patients $(9.96 \%)$ was the third most common genotype. M694V/M680I was detected in 25patients $(8.85 \%)$, and it was determined as the 4th most common genotype. Other common genotypes were V726A heterozygous mutation, M680I heterozygous mutations. E148Q homozygous, V726A homozygous, and various combined heterozygous mutations were rare genotypes. The mutation frequencies of the patients in our study are shown in Table 3.

\section{Association of Genotype with Disease Severity Scores}

We observed that 47 patients belonged to the mild disease group, 198 patients belonged to the

Table 1: Disease Severity Scoring System in FMF

\begin{tabular}{|c|c|c|c|c|c|}
\hline \multicolumn{3}{|l|}{ Pras et al. Disease Severity Scoring System } & \multirow{2}{*}{$\begin{array}{l}\text { Mor et al. Disease Severity Scoring System } \\
\text { Criteria }\end{array}$} & \multicolumn{2}{|l|}{$\begin{array}{l}\text { ISSF (International Severity Scoring System for Familial } \\
\text { Mediterranean Fever) }\end{array}$} \\
\hline Parameter & Feature & Score & & Criteria & Score \\
\hline \multirow{5}{*}{ Age of onset (year) } & $>31$ & 0 & \multirow{5}{*}{$\begin{array}{l}1, \geq 1 \text { site in a single attack (In at least } 25 \% \text { of } \\
\text { the attacks) }\end{array}$} & \multirow{2}{*}{$\begin{array}{l}\text { 1. Chronic sequela (including amyloidosis, } \\
\text { growth retardation, anaemia, splenomegaly) }\end{array}$} & \multirow{2}{*}{1} \\
\hline & $21-31$ & 1 & & & \\
\hline & $11-20$ & 2 & & & \\
\hline & $6-10$ & 3 & & $\begin{array}{l}\text { 2. Organ dysfunction (nephrotic range proteinu- } \\
\text { ria, FMF related) }\end{array}$ & 1 \\
\hline & $<6$ & 4 & & & \\
\hline \multirow{3}{*}{ Number of attacks per month } & $<1$ & 1 & \multirow{3}{*}{ 2. $\geq 2$ sites in the course of the disease } & \multirow{3}{*}{ 3. Organ failure (heart, renal, etc, FMF related) } & \multirow{3}{*}{1} \\
\hline & $1-2$ & 2 & & & \\
\hline & $>2$ & 3 & & & \\
\hline \multirow{2}{*}{ Arthritis } & Acute & 2 & \multirow{2}{*}{$\begin{array}{l}\text { 3. } \geq 2 \mathrm{mg} / \text { day colchicine to achieve } \\
\text { remission }\end{array}$} & $\begin{array}{l}\text { 4. A. Frequency of attacks (average number of } \\
\text { attacks between } 1 \text { and } 2 \text { per month) }\end{array}$ & 1 \\
\hline & Persistent & 3 & & $\begin{array}{l}\text { B. Frequency of attacks (average number of } \\
\text { attacks }>2 \text { per month) }\end{array}$ & 2 \\
\hline Erysipelas-Like erythema & & 2 & $\begin{array}{l}\text { 4. } \geq 2 \text { pleuritic attacks during the course of } \\
\text { the disease }\end{array}$ & $\begin{array}{l}\text { 5. Increased acute-phase reactants (any of } \\
\text { C-reactive protein, serum amyloid } A \text {, eryth- } \\
\text { rocyte sedimentation rate, fibrinogen) during } \\
\text { the attack-free period, } \geq 2 \text { weeks after the last } \\
\text { attack (at least two times } 1 \text { months apart) }\end{array}$ & 1 \\
\hline Amyloidosis & & 3 & $\begin{array}{l}\text { 5. } \geq 2 \text { Erysipelas-like erythema attacks during } \\
\text { the courseof the disease }\end{array}$ & $\begin{array}{l}\text { 6. Involvement of more than two sites during an } \\
\text { individual acute attack (pericarditis, pleuritis, } \\
\text { peritonitis, synovitis, ELE, testis involvement, } \\
\text { myalgia, and so on) }\end{array}$ & 1 \\
\hline \multirow{4}{*}{ Colchicine Dosage (mg/day) } & 1 & 1 & \multirow{4}{*}{ 6. Age of onset< 10 years } & \multirow{4}{*}{$\begin{array}{l}\text { 7. More than two different types of attack } \\
\text { during the course of the disease (isolated fever, } \\
\text { pericarditis, pleuritis, peritonitis, synovitis, ELE, } \\
\text { testis involvement, myalgia, and so on) }\end{array}$} & \multirow{4}{*}{1} \\
\hline & 1,5 & 2 & & & \\
\hline & 2 & 3 & & & \\
\hline & $>2 * *$ & 4 & & & \\
\hline \multirow{3}{*}{$\begin{array}{l}* 2 \mathrm{mg} / \text { day unresponsive } \\
3-5 \text { points were classified as mild disease, } 6 \\
\text { disease, and }>10 \text { as severe disease. }\end{array}$} & & & \multirow{3}{*}{$\begin{array}{l}\geq 3 \text { points was considered as severe disease, } \\
2 \text { points as moderate disease, and } \leq 1 \text { points } \\
\text { as mild disease. }\end{array}$} & $\begin{array}{l}\text { 8. Duration of attacks (more than } 72 \mathrm{~h} \text { in at least } \\
\text { three attacks in a year) }\end{array}$ & 1 \\
\hline & 6-9 points a & loderate & & $\begin{array}{l}\text { 9. Exertional leg pain (pain following prolonged } \\
\text { standings and/or exercising, excluding other } \\
\text { causes) }\end{array}$ & 1 \\
\hline & & & & \multicolumn{2}{|c|}{$\begin{array}{l}\text { Severe disease } \geq 6 \text {, intermediate disease } 3-5 \text {, mild disease } \\
\leq 2 .{ }^{*} \text { Criterion } 4 \mathrm{a} / 4 \mathrm{~b} \text { can give } 0 \text { or } 1 \text { or } 2 \text { points altogether } \\
\text { according to the definition. }\end{array}$} \\
\hline
\end{tabular}


Table 2: Clinical and Demographic Features of The Patients with Familial Mediterranean Fever

\begin{tabular}{|c|c|c|}
\hline Variables & Median & Min-Max \\
\hline Age (Year) & 8 & $0.83-18$ \\
\hline Age of Diagnosis (Year) & 7 & $0.83-18$ \\
\hline Time to Diagnosis & 2 & $0.2-13$ \\
\hline Attack Duration(Day) & 3 & $0.25-10$ \\
\hline Attack Frequency (Week) & 4 & $1-72$ \\
\hline Gender & $n=303$ & $\%$ \\
\hline Female & 149 & 49.1 \\
\hline Male & 154 & 50.8 \\
\hline Clinical Features & $n=303$ & \\
\hline Abdominal Pain & 290 & 95.7 \\
\hline Continuous & 262 & 86.5 \\
\hline Colic & 28 & 9.2 \\
\hline Fever & 283 & 93.4 \\
\hline $37 C^{0}-38 C^{0}$ & 29 & 9.6 \\
\hline$\geq 38 \mathrm{C}^{0}$ & 254 & 83.8 \\
\hline Joint Pain & 164 & 54.1 \\
\hline Fatique & 80 & 26.4 \\
\hline Chest Pain & 64 & 21.1 \\
\hline Arthritis & 46 & 15.2 \\
\hline Ankle & 29 & 9.6 \\
\hline Knee & 15 & 5 \\
\hline Other Joints & 8 & 2.6 \\
\hline Nausea-Vomiting & 35 & 11.6 \\
\hline Constipation & 27 & 8.9 \\
\hline Diarrhea & 20 & 6.6 \\
\hline Headache & 14 & 4.6 \\
\hline Myalgia & 11 & 3.6 \\
\hline Unrest & 11 & 3.6 \\
\hline Erysipelas-like rash & 8 & 2.6 \\
\hline
\end{tabular}

moderate disease group, and 58 patients belonged to the severe disease group according to the scoring system described by Pras et al. Further, we observed that 199 patients belonged to the mild disease group, 43 patients belonged to the moderate disease group, and 61 patients belonged to the severe disease group according to the scoring system described by Mor et al. Additionally, we observed that 176 patients belonged to the mild disease group, 106 patients belonged to the moderate disease group, and 21 patients belonged to the severe disease group according to the ISSF scoring system. Patients with homozygous, heterozygous, heterozygous combined, and no mutations were evaluated according to disease severity scores (Pras et al., Mor et al., and ISSF), and no difference was found between the genotypes in terms of disease severity according to all three scoring
Table 3: Mutation Frequency of Patients

\begin{tabular}{|c|c|}
\hline Mutation & n (\%) \\
\hline M694V heterozygous & $63(23.2)$ \\
\hline M694V homozygous & $43(15.8)$ \\
\hline El $48 Q$ heterozygous & $27(9.96)$ \\
\hline M694V-M680I compound heterozygous & $25(9.22)$ \\
\hline V726A heterozygous & $18(6.64)$ \\
\hline M680I heterozygous & $14(5.16)$ \\
\hline M694V-V726A compound heterozygous & $11(4.05)$ \\
\hline M680I-V726A compound heterozygous & $10(3.69)$ \\
\hline R202Q heterozygous & $8(2.95)$ \\
\hline M680I homozygous & $7(2.58)$ \\
\hline M694V-El48Q compound heterozygous & $5(1.84)$ \\
\hline R202Q homozygous & $4(1.47)$ \\
\hline V726A-El48Q compound heterozygous & $4(1.47)$ \\
\hline El48Q homozygous & $3(1.10)$ \\
\hline M694V-R202Q compound heterozygous & $3(1.10)$ \\
\hline M694V-M680I-R202Q compound heterozygous & $2(0.73)$ \\
\hline V726A homozygous & $2(0.73)$ \\
\hline V726A-R202Q compound heterozygous & $2(0.73)$ \\
\hline M694V-U148Q compound heterozygous & $2(0.73)$ \\
\hline M680I-E148Q compound heterozygous & $2(0.73)$ \\
\hline Other* & $16(5.90)$ \\
\hline Total & $271(100)$ \\
\hline
\end{tabular}

*Rare mutations, one each.(A744S heterozygous, E148Q-P369S compound hererozygous, R202Q-R761H

compound heterozygous, M680I-R202Q compound heterozygous, M694V-R761U compound heterozygous,

V722M heterozygous, R761U heterozygous, M694V-L110P compound heterozygous, M694l heterozygous,

P369S heterozygous, M694V-E230K compound heterozygous, E230K heterozygous, R202Q- A744S compound

heterozygous, V726A-M694I compound heterozygous, M694V-R202QEl 48Q compound heterozygous, M680I-

$\mathrm{R} 761 \mathrm{H}$ compound heterozygous)

systems ( $p=0.571, p=0.630$, and $p=0.546$, respectively). The evaluation of genotypes according to disease severity scores is shown in Table 4.

When patients were grouped as homozygous M694V, heterozygous M694V, heterozygous M694V/other allele and other mutations, a statistical difference was found between the groups in terms of disease severity scores according to Pras et al. ( $p=0.017)$. According to the score of Pras et al., the frequency of mild disease tended to be less in the M694V homozygous group. However, no statistically significant difference was found between the groups according to Mor et al. and ISSF ( $p=0.608,0.336$, respectively) (Table 4 ).

When the patients with homozygous M694V, heterozygous M694V, heterozygous E148Q, and heterozygous M694V/M680I combined mutations, which were the most common mutations in our study, were compared in terms of disease severity scores according to the scoring system described by Pras et al., a significant difference was observed between 
the groups, and mild disease was found to be less common in the homozygous M694V group ( $p=0.037$ ). However, there was no difference between them in terms of disease severity accoring to the scoring system described by Mor et al. and the ISSF (Table 4).

When the group with heterozygous M694V and the groups with heterozygous $\mathrm{M} 680 \mathrm{l}$, heterozygous V726A, heterozygous E148Q, and heterozygous R202Q mutations, which were other common mutations, were compared, no difference was found between the mild-moderate and severe groups in terms of disease severity according to the three scoring systems ( $p=0.609, p=0.697$, and $p=0.519$, respectively).

When the homozygous M694V group and the group with heterozygous M694V (combined with other allele or single) mutation were compared in terms of disease severity, a significant correlation was found indicating that the disease was more severe in the homozygous M694V group based on the three scoring systems ( $p=0.001, p=0.024$, and $p=0.050$, respectively) (Table $5)$. When the direction of the correlation in the scores according to the scoring system described by Pras ef al. was examined, it was observed that there were more patients with severe disease than those with mild disease in the group with homozygous mutations, and the heterozygous group tended to have more patients with severe disease than those with mild disease. With post hoc analysis, according to Pras et al.'s scoring system, those with mild disease were significantly higher in the heterozygous group compared to the homozygous group $(z=2.5, x 2=6.25, p=0.04)$, while those with severe disease were significantly higher in the homozygous group than those with mild disease. $(\mathrm{z}=-2.5, \quad \mathrm{X} 2=6.25, \mathrm{p}=0.04)$. In the scoring system described by Mor et al., the group with homozygous mutation had a tendency to have severe disease, whereas there was a tendency to have mild disease in the group with heterozygous mutation. In post hoc analysis, the $p$ value was found to be 0.07 in both directions $(z=-2.3, x 2=5.9, z=2.3, x 2=5.9$, respectively). It was not statistically significant. According to the ISSF classification, mild disease was found to be more common in patients with heterozygous mutation but this was not statistically significant according to $p<0.05$.

When patients with and without the M694V allele were evaluated in terms of the disease severity scores according to the scoring systems described by Pras et al. and Mor et al. and the ISSF, no difference was found between the groups in terms of disease severity $(p=0.453, p=0.657$, and 0.336 , respectively).

When we grouped and compared the disease severity scores of heterozygous mutations of the common alleles M694V, M680I, V726A, and El48Q as mild-moderate and severe, no difference was found between the groups according to all three disease severity scoring systems $(p=0.766, p=0.939$, and $p=0.964$, respectively).

In addition, when we classified the M680I and V726A mutations, which were the second and third most common mutations, into homozygous and heterozygous mutations and compared them based on mild-moderate and severe in terms of disease severity scores, no significant difference was found between the groups in terms of disease severity. When the patients with and without the M680 allele and the patients with and without the V726A allele were compared in terms of disease severity scores, no significant difference was found between the groups.

Similarly, in terms of E148Q and R202Q, which were other common mutations, no difference was found between the groups having homozygous and heterozygous mutations according to all three scoring systems when grouped based on the severity of the disease as mild-moderate and severe. There was no difference in disease severity between patients with and without the El48Q allele. When the presence and absence of the R202Q allele and disease severity scores were compared, no significant correlation was found.

Although there was no homozygous mutation among other mutations, including M694I, R761H, A744S, E130K, P369S, R761U, and V722M, when patients with heterozygous mutations and those without mutations were compared, no difference was found in terms of disease severity according to the three disease severity scoring systems. When the internal consistency of the scoring systems were evaluated with the SDATA statistical program Kappa analysis, a weak agreement was detected among Pras et al. SS and Mor et al. SS with kappa value of 0.357 , agreement value of $80.12 \%$, $\mathrm{p}<0.01$. A weak agreement was found between Pras et al. SS and ISSF with a kappa value of 0.297 , an agreement value of $81.85 \%$, and $p<0.01$. However, a strong (good) agreement was found between the Mor et al. SS and ISSF, with a kappa value of 0.661 , an agreeement value of $91.17 \%$, and a $p<0.01$..

\section{DISCUSSION}

Due to the developments in the field of molecular genetics, we have been able to gain more knowledge regarding the FMF, which we assumed to have known about for a long time. In fact, genetic examination was added to the EURO Fever/PRINTO diagnostic criteria defined in 2019 for this disease, which was being diagnosed based on clinical criteria only, and the importance of genetic examination was revealed. Many mutations in the MEFV gene that cause FMF have been identified with recent studies on molecular genetics (12).

In the last 20 years, disease severity scores have been developed to determine the severity, prognosis and effective treatment of many diseases, including FMF. In FMF, the disease severity score, which was first developed by Pras et al.in 1997, was used for adult patients (8). In 2005, Mor et al. has been developed to a new scoring system to correct missing conditions such as lack of cause and effect relationship between severity markers and disease severity in Pras disease severity score. (9). Finally, in 2012, the international group of FMF experts developed the ISSF criteria. These criteria are suitable for use in children and adults in 
Table 4: Evaluation of Genotypes According to Disease Severity Scores

\begin{tabular}{|c|c|c|c|c|c|c|}
\hline & & $\begin{array}{l}\text { Heterozygous n:136 } \\
\text { (\%) }\end{array}$ & $\begin{array}{l}\text { Homozygous n:59 } \\
\text { (\%) }\end{array}$ & $\begin{array}{l}\text { Compound heterozy- } \\
\text { gous } n: 76(\%)\end{array}$ & $\begin{array}{l}\text { No Mutation n:32 } \\
\text { (\%) }\end{array}$ & $\mathrm{p}$ \\
\hline \multirow{3}{*}{$\begin{array}{l}\text { Pras } \\
\text { et al. SS }\end{array}$} & Mild & 25 (18.4) & $3(5.1)$ & $12(15.8)$ & $7(21.9)$ & \\
\hline & Moderate & $88(64.7)$ & 37 (62.7) & $50(65.8)$ & 23 (71.9) & 0.571 \\
\hline & Severe & $23(16.9)$ & 19 (32.2) & $14(18.4)$ & $2(6.3)$ & \\
\hline \multirow{3}{*}{$\begin{array}{l}\text { Mor } \\
\text { et al. SS }\end{array}$} & Mild & $94(69.1)$ & $30(50.8)$ & $50(65.8)$ & $25(78.1)$ & \\
\hline & Moderate & 18 (13.2) & $11(18.6)$ & $9(11.8)$ & $5(15.6)$ & 0.63 \\
\hline & Severe & $24(17.6)$ & 18 (30.5) & $17(22.4)$ & $2(6.3)$ & \\
\hline \multirow{3}{*}{ ISSF } & Mild & $82(60.3)$ & $26(44.1)$ & $47(61.8)$ & $21(65.6)$ & \\
\hline & Moderate & $47(34.6)$ & $24(40.7)$ & $24(31.6)$ & 11 (34.4) & 0.546 \\
\hline & Severe & $7(5.1)$ & $9(15.3)$ & $5(6.6)$ & $0(0)$ & \\
\hline \multirow{4}{*}{$\begin{array}{l}\text { Pras } \\
\text { et al. SS }\end{array}$} & & $\begin{array}{l}\text { M694V Heterozygous } \\
\text { n: } 63(\%)\end{array}$ & $\begin{array}{l}\text { M694V Homozygous } \\
\text { n: } 43 \\
(\%)\end{array}$ & $\begin{array}{l}\text { M694V/Other Com- } \\
\text { pound heterozygous } \\
\text { n: } 52 \\
(\%)\end{array}$ & $\begin{array}{l}\text { Other Mutations n: } 110 \\
\text { (\%) }\end{array}$ & \\
\hline & Mild & $12(19)$ & $1(2.3)$ & $8(16)$ & $9(8.1)$ & \multirow{3}{*}{0.017} \\
\hline & Moderate & $42(66.6)$ & $27(62.8)$ & 35 (67.3) & $68(61.8)$ & \\
\hline & Severe & $9(14.2)$ & $15(34.9)$ & $9(17.3)$ & $33(30)$ & \\
\hline \multirow{3}{*}{$\begin{array}{l}\text { Mor } \\
\text { et al. SS }\end{array}$} & Mild & 45 (71.9) & $23(53.5)$ & $33(63.4)$ & $72(65.5)$ & \multirow{3}{*}{0.608} \\
\hline & Moderate & $9(14.1)$ & $8(18.6)$ & $7(13.4)$ & 14 (12.7) & \\
\hline & Severe & $9(14.1)$ & 12 (27.9) & $12(23.0)$ & $24(21.8)$ & \\
\hline \multirow{3}{*}{ ISSF } & Mild & $40(64.1)$ & $20(46.5)$ & $31(59.6)$ & $62(56.4)$ & \multirow{3}{*}{0.336} \\
\hline & Moderate & $20(31.3)$ & $16(37.2)$ & 17 (32.6) & 41 (37.3) & \\
\hline & Severe & $3(4.7)$ & $7(16.3)$ & $4(7.69)$ & $7(6.4)$ & \\
\hline \multirow{4}{*}{$\begin{array}{l}\text { Pras } \\
\text { et al. SS }\end{array}$} & & $\begin{array}{l}\text { M694V Heterozygous } \\
\text { n:63 } \\
(\%)\end{array}$ & $\begin{array}{l}\text { M694V Homozygous } \\
\mathrm{n}: 43(\%)\end{array}$ & $\begin{array}{l}\text { E148Q Heterozygous n:27 } \\
\text { (\%) }\end{array}$ & $\begin{array}{l}\text { M694V/M680I Com- } \\
\text { pound Heterozygous } \\
\text { n: } 25 \\
\text { (\%) }\end{array}$ & \multirow{4}{*}{0.037} \\
\hline & Mild & $12(19)$ & $1(2.3)$ & $5(18.5)$ & $5(20.0)$ & \\
\hline & Moderate & $42(66.6)$ & 27 (62.8) & 17 (63.0) & $15(60.0)$ & \\
\hline & Severe & $9(15.3)$ & 15 (34.9) & $5(18.5)$ & $5(20.0)$ & \\
\hline \multirow{3}{*}{$\begin{array}{l}\text { Mor } \\
\text { et al. SS }\end{array}$} & Mild & 45 (71.9) & $23(53.5)$ & $18(66.7)$ & $15(60.0)$ & \multirow{3}{*}{0.466} \\
\hline & Moderate & $9(14.1)$ & $8(18.6)$ & $5(18.5)$ & $5(20.0)$ & \\
\hline & Severe & $9(14.1)$ & $12(27.9)$ & 4 (14.8) & $5(20.0)$ & \\
\hline \multirow{3}{*}{ ISSF } & Mild & $40(64.1)$ & $20(46.5)$ & $17(63.0)$ & $14(56.0)$ & \multirow{3}{*}{0.220} \\
\hline & Moderate & $20(31.3)$ & $16(37.2)$ & $9(33.3)$ & $9(36.0)$ & \\
\hline & Severe & $3(4.7)$ & $7(16.2)$ & $1(3.7)$ & $2(8.8)$ & \\
\hline
\end{tabular}

both clinical practice and drug trials (10).

Disease severity scores are now used in many diseases to evaluate disease severity more objectively. In previous studies, it was found that the disease severity scores showed more severe disease in the group carrying the homozygous M694V mutation (13-15).
However, in a study from Turkey, it was observed that carrying the M694V mutation in one allele or two alleles did not change the severity of the disease (16). In another study, no difference was observed in terms of disease severity scores between common mutations (M694V, V726A, and M680I) and rare mutations (A744S, P369S, K695R, R761H, and F479L) 
Table 5: Evaluation of M694V Homozygous and Heterozygous Mutations According to Patient Weight Scores

\begin{tabular}{cc} 
M694V & \multicolumn{2}{c}{ M694V Heterozygous } \\
Homozygous & $\begin{array}{l}\text { (combined with other allele } \\
\text { or single) }\end{array}$ \\
$\mathrm{n=43}(\%)$ & \multicolumn{1}{c}{ (\%) }
\end{tabular}

$\begin{array}{lccc}\text { Pras et al. SS } & 1(2.3) & 20(17.3) & \\ \text { Mild } & 27(62.7) & 77(66.9) & 0.004 \\ \text { Moderate } & 15(34.8) & 18(15.6) & \\ \text { Severe } & 23(53.5) & 79(68.6) & 0.024 \\ \text { Mor et al. SS } & 8(18.6) & 14(12.1) & \\ \text { Mild } & 18(27.9) & 22(19.1) & \\ \text { Moderate } & & 72(62.6) & 0.050 \\ \text { Severe } & 20(46.5) & 36(31.3) & \\ \text { ISSF } & 16(37.2) & 7(6.0) & \end{array}$

(17). In a study that only aimed to evaluate the association of E148Q mutation with disease severity and evaluated homozygous M694V mutation with homozygous El48Q, heterozygous El48Q and heterozygous El48Q/Exon 10 combined mutations according to the scoring system described by Pras et al., it was observed that the disease had a more severe course in patients with homozygous M694V mutation (18). In the present study, according to the scoring system described by Pras et al., a correlation was found between homozygous M694V, heterozygous M694V, heterozygous M694V/other combined, and other genotypes, indicating that the rate of mild disease was lower in the M694V homozygous group. Similarly, a relationship was found in terms of disease severity in the comparison of the four most common genotypes: homozygous M694V, heterozygous M694V heterozygous E148Q, and heterozygous M694V/M680I combined. In addition, when only homozygous M694V and heterozygous M694V groups were compared in pairs, the rate of severe disease tended to be higher in the homozygous group according to all three scoring systems. However, this was not statistically significant according to the scoring system described by Mor et al. and the ISSF. Based on the scoring system described by Pras et al., the rate of severe disease was higher in patients with homozygous M694V allele, whereas the rate of mild disease was statistically significantly higher in the heterozygous group compared with homozygous group. In light of all of these findings, we can say that the homozygous M694V mutation is associated with a more severe disease than other mutations that are common in the population. However, a sound comparison of homozygous M694V and other homozygous mutations could not be made as the incidence of homozygous mutation of other alleles (V726A, El48Q, and M680I) is very low in the population.

Although ISSF scoring was found to be the most appropriate scoring system for children in a recent study conducted in our country, we observed that other scoring systems are used more widely when the literature is examined. $(18,19,20,21)$. In our study, unlike other studies, 3 disease severity scores were used and in fact, the compatibility of these disease severity scores with each other was tried to be seen. According to our study, the results in the scoring system of Pras et al. were different from the scoring system of ISSF and Mor et al. As a matter of fact, in the concordance analysis between scoring systems, while a good agreement was found between Mor et al.'s scoring system and ISSF, the agreement with Pras et al.'s scoring system was weak.

Therefore, although patients with FMF were evaluated across a wide range in terms of genetic, and disease severity scores, the most important limitation of the study was the inability to perform statistical analysis due to the low number of patients for some genotypes.

We believe that further studies are warranted with large samples, multiple centers and even multiple ethnic groups for evaluating the relationship between clinical presentation and genotype and their relationship with disease severity scores in order to better understand FMF. Additionally, this will aid in the understanding of the effects of genetic mutations that have recently been added to the diagnostic criteria on clinical presentation and disease severity.

Acknowledgements: The authors thank Enago https://www.enago.com.tr/ceviri/ for their assistance in manuscript translation and editing.

\section{Funding: None}

Conflict of Interest: The authors declare that there is no conflict of interest.

Author's Contributions: All authors contributed to the study conception and design. Material preparation, data collection and analysis were performed by Vildan Güngörer, Alaaddin Yorulmaz and Şükrü Arslan. The first draft of the manuscript was written by Vildan Güngörer and all authors commented on previous versions of the manuscript. All authors read and approved the final manuscript.

\section{References}

1.Ozen S, Bilginer Y. A clinical guide to autoinflammatory diseases: familial Mediterranean fever and next-of-kin. Nat Rev Rheumatol. $2014 ; 10: 135-47$

2.Yalçınkaya F, Group TFS. Familial Mediterranean fever (FMF) in Turkey: results of a nationwide multicenter study. 2005.

3.Lidar $M$, Livneh A. Familial Mediterranean fever: clinical, molecular and management advancements. Neth J Med. 2007; 65: 318-24.

4.Cobankara V. Kiraz S. Ailesel akdeniz ateşi Hacettepe Tıp Dergis Hacettepe Üniversitesi yayınları Ankara. 2000; 31: 310-9.

5.Tufan A, Lachmann HJ. Familial Mediterranean fever, from pathogenesis to treatment: a contemporary review. Turk J Med Sci. 2020;50: 1591-610. 
6.Consortium FF. A candidate gene for familial Mediterranean fever. Nature genetics. 1997; 17: 25-31.

7.Schnappauf O, Chae JJ, Kastner DL, Aksentijevich I. The Pyrin Inflammasome in Health and Disease. Front Immunol. 2019; 10: 1745.

8.Pras E, Livneh A, Balow Jr JE, et al. Clinical differences between North African and Iraqi Jews with familial Mediterranean fever. American journal of medical genetics. 1998; 75: 216-9.

9.Mor A, Shinar Y, Zaks N, et al., editors. Evaluation of disease severity in familial Mediterranean fever. Seminars in arthritis and rheumatism: 2005: Elsevier.

10.Demirkaya E, Acikel C, Hashkes P, et al. Development and initial validation of international severity scoring system for familial Mediterranean fever (ISSF). Annals of the Rheumatic Diseases. 2016 75: 1051-6.

11.Yalçınkaya F, Özen S, Özçakar ZB, et al. A new set of criteria for the diagnosis of familial Mediterranean fever in childhood. Rheumatology. 2009; 48: 395-8.

12.Gattorno $M$, Hofer $M$, Federici S, et al. Classification criteria for autoinflammatory recurrent fevers. Annals of the rheumatic diseases. 2019;78: 1025-32.

13.Battal F, Silan F, Topaloğlu N, et al. The MEFV gene pathogenic variants and phenotype-genotype correlation in children with familial Mediterranean fever in the Çanakkale population. Balkan journal of medical genetics: BJMG. 2016; 19: 23.

14. Wilson M, Abou-Elalla AA, Zakaria MT,et al. Serum amyloid A Type 1 gene polymorphism in Egyptian children with familial Mediterranean fever. Pathobiology. 2016; 83: 295-300.

15.Yavuz S, Duru NS, Elevli M. Ailevi Akdeniz Ateşi Hastalarında Klinik, Laboratuvar Bulguları, Hastalık Ağırlık Skorları ve Gen Mutasyonları Arasındaki İlişki. Medical Bulletin of Haseki/Haseki Tip Bulteni. 2018; 56 : 58-64..

16.Yalçınkaya F, Cakar N, Mısırlıŏlu M, et al. Genotypephenotype correlation in a large group of Turkish patients with familial Mediterranean fever: evidence for mutation-independent amyloidosis. Rheumatology. 2000; 39: 67-72.

17.Soylemezoglu O, Kandur Y, Duzova A, et al. Familial Mediterranean fever with a single MEFV mutation: comparison of rare and common mutations in a Turkish paediatric cohort. Clinical and experimental rheumatology. 2015; 33: 152-5.

18.Aydın F, Çakar N, Özçakar ZB, et al. Clinical features and disease severity of Turkish FMF children carrying E148Q mutation. J Clin Lab Anal. 2019; 33: e22852.

19.Ayaz NA, Tanatar A, Karadag SG, et al. Comorbidities and phenotype-genotype correlation in children with familial Mediterranean fever. Rheumatol Int. 2021; 41: 113-20.

20.Guler T, Garip Y, Dortbas F, Dogan YP. Quality of life in Turkish patients with Familial Mediterranean Fever: Association with fatigue, psychological status, disease severity and other clinical parameters. The Egyptian Rheumatologist. 2018; 40: 117-21.

21.Ozcan G, Cayci S, Celikel Acar B et al. Is the performance of the international severity scoring system for familial mediterranean fever in children better than other scoring systems? International Journal of Clinical Practice, 2021, 75.11: e14678. doi: 10.1111/ijcp.14678. Epub 2021 Aug 18. PMID: 34328662. 